\title{
Proteomic analysis of the venom of the predatory ant Pachycondyla striata (Hymenoptera: Formicidae)
}

\author{
Pollyanna Pereira Santos ${ }^{1,2}$ | Patricia Dias Games ${ }^{3}$ \\ Dihego Oliveira Azevedo ${ }^{4}$ | Edvaldo Barros ${ }^{5}$ \\ Leandro Licursi de Oliveira ${ }^{3}$ Humberto Josué de Oliveira Ramos ${ }^{5}$ \\ Maria Cristina Baracat-Pereira ${ }^{5}$ | José Eduardo Serrão ${ }^{3}$ (iD
}

\footnotetext{
${ }^{1}$ Coordenação de Ciências Naturais, Universidade Federal do Maranhão, Bacabal, Maranhão, Brazil

${ }^{2}$ Departamento de Entomologia, Universidade Federal de Viçosa, Viçosa, Minas Gerais, Brazil

${ }^{3}$ Departamento de Biologia Geral, Universidade Federal de Viçosa, Viçosa, Minas Gerais, Brazil

${ }^{4}$ Instituto Federal do Espirito Santo, Ibatiba,

Espirito Santo, Brazil

${ }^{5}$ Departamento de Bioquímica e Biologia Molecular, Universidade Federal de Viçosa,

Viçosa, Minas Gerais, Brazil

Correspondence

José Eduardo Serrão, Departamento de Biologia Geral, Universidade Federal de Viçosa (UFV), Avenida Peter Henry Rolfs, s/n- Campus Universitário, Viçosa, MG 36570-900, Brazil. Email:jeserrao@ufv.br
}

\begin{abstract}
The ants use their venom for predation, defense, and communication. The venom of these insects is rich in peptides and proteins, and compared with other animal venoms, ant venoms remain poorly explored. The objective of this study was to evaluate the protein content of the venom in the Ponerinae ant Pachycondyla striata. Venom samples were collected by manual gland reservoir dissection, and samples were submitted to two-dimensional gel electrophoresis and separation by ion-exchange and reverse-phase high-performance liquid chromatography followed by mass spectrometry using tanden matrix-assisted laser desorption/ionization with time-of-flight (MALDI-TOF/TOF) mass spectrometry and electrospray ionization-quadrupole with time-of-flight (ESI-Q/TOF) mass spectrometry for obtaining amino acid sequence. Spectra obtained were searched against the NCBInr and SwissProt database. Additional analysis was performed using PEAKS Studio 7.0 (Sequencing de novo). The venom of $P$. striata has a complex mixture of proteins from which 43 were identified. Within the identified proteins are classical venom proteins (phospholipase $A$, hyaluronidase, and aminopeptidase $\mathrm{N}$ ), allergenic proteins (different venom allergens), and bioactive peptides (U10-ctenitoxin Pn1a). Venom allergens are among the most expressed proteins, suggesting that $P$. striata venom has high allergenic potential. This study discusses the possible functions of the proteins identified in the venom of P. striata.
\end{abstract}

MALDI-TOF/TOF, peptides, proteins, Q-TOF, toxin, venom 


\section{I INTRODUCTION}

The venom of the animals can be broadly defined as a secretion produced by specialized glands that when injected into a target organism are able to disrupt normal physiological or biochemical processes, facilitate feeding, or defense by the producing animal (Casewell, Wuster, Vonk, Harrison, \& Fry, 2013).

Venoms arose at different times and through different lineages of evolutionary history (Casewell et al., 2013), and is currently limited to a few animal groups (Escoubas, Quinton, \& Nicholson, 2008) including insects.

The venom of bees, wasps, and ants (Hymenoptera) is a complex mixture of hydrocarbons, salts, sugars, biogenic amines, alkaloids, free amino acids, formic acid, proteins, peptides, and other bioactive compounds (Aili et al., 2014; Santos, Pieroni, Menegasso, Pinto, \& Palma, 2011; Touchard et al. 2014; Touchard, Dejean, Escoubas, \& Orivel, 2015). Pioneering studies have demonstrated that the venoms of stinging ants are mostly composed of small peptides, similarly to other venomous animals (Aili et al., 2014; Touchard et al., 2014, 2015, 2016b). However, a wide variety of proteins has also been described in the venom of different species of ants (Touchard et al., 2016a).

Ants employ venoms for a variety of purposes including predation and defense against predators and competitors, defense against microbial pathogens, social communication (Orivel \& Dejean, 2001; Touchard et al., 2016a), and as herbicides (Touchard et al., 2016a). However, ant venoms remain almost unexplored in comparison with other animals (Aili et al., 2017; Rifflet et al., 2012; Touchard et al., 2014). The species of ants with the most well-characterized venoms are the fire ant Solenopsis invicta and Solenopsis saevissima and Myrmecia pilosula (Santos et al., 2011; Touchard et al., 2016a).

Peptides with neurotoxic activity have been identified in the venom of different species of ants. Poneratoxin, ectatomin, and poneritoxin are substances that affect ion channels (Piek et al., 1991; Pluzhnikov et al., 1999; Touchard et al., 2016a), and were isolated from the venom of Paraponera clavata (Paraponerinae), Ectatomma tuberculatum (Ectatomminae), and Anochetus emarginatus (Ponerinae), respectively. Additionally, the venom of ants has myotoxin in S. invicta (Pinto et al., 2012), phospholipase (PL) A and B in S. invicta (Baer et al., 1979; Pinto et al., 2012), Pogonomyrmex badius (Schmidt \& Blum, 1978), and Myrmecia pyriformis (Lewis, Day, \& De La Lande, 1968), and hyaluronidase, lipases, acid phosphatase, and esterase in P. badius (Schmidt \& Blum, 1978) that induce cell necrosis. The presence of bioactive peptides indicates that the venom of ants may be a potential source for design of new therapeutic drugs.

In Ponerinae ants, studies of protein content in the venom were carried out in Pseudoneoponera insularis (former Pachycondyla insularis) (Maschwitz, Jessen, \& Maschwitz, 1981), Dinoponera grandis (Leluk, Schmidt, \& Jones, 1989), Odontoponera transversa (Leluk et al., 1989), Neoponera goeldii (former Pachycondyla goeldii) (Orivel \& Dejean, 2001), Dinoponera australis (Johnson, Copello, Evans, \& Suarez, 2010), Dinoponera quadriceps (Cologna et al., 2013), Neoponera villosa (former Pachycondyla villosa) (Pessoa et al., 2016), and Anochetus emarginatus (Touchard et al., 2016b). Although some of the venom components of ants have been isolated and characterized (Orivel \& Dejean, 2001; Morgan et al., 2003; Szolajska et al., 2004; Wiese et al., 2006), there are few data on its composition, chemical, and pharmacological properties.

Pachycondyla striata (Ponerinae) has a distinguished behavior, producing a foamy substance from terminal abdominal region, as a defense mechanism. The venom, released as a foam-like substance (Mackay \& Mackay, 2010), has been also reported in Pachycondyla tridentata and Pseudoneoponera insularis (former P. insularis) (Maschwitz et al., 1981). However the venom compounds in this ant remains unknown. Thus, the objective of this study was evaluate the protein composition of the venom in the predatory ant P. striata, collected in the state of Minas Gerais, Brazil.

\section{I MATERIALS AND METHODS}

\subsection{Study sites and sample preparation}

Fifteen nests of $P$. striata were collected in Viçosa $\left(20^{\circ} 48^{\prime} S 42^{\circ} 51^{\prime}\right.$ W), state of Minas Gerais, Brazil. A specimen of each colony was taxonomically identified and deposited in the Collection of Mimercologia/CEPEC/CEPLAC in Ilhéus, state of Bahia, Brazil. 
Eighty workers from different colonies of $P$. striata were cryoanesthetized and the venom reservoir, without the venom gland, transferred to $10 \% \mathrm{w} / \mathrm{v}$ protease inhibitor cocktail (Sigma-Aldrich, St. Louis, Missouri, USA). Each gland was gently disrupted with tweezers and the sample was centrifuged at $13,700 \times g$ for 15 min at $4^{\circ} \mathrm{C}$ and the supernatant was collected. Each sample had 80 venom reservoir randomly collected from the 15 nests. The amount of protein in the extract was determined by the bicinchoninic acid method (Smith et al., 1985), using bovine serum albumin as standard.

\section{2 | Two-dimensional gel electrophoresis}

The immobilized pH gradient (IPG) strips 7 cm, pH 3-10 linear, (GE-Healthcare, Milwaukee, Wisconsin, USA) were rehydrated for $10 \mathrm{~h}$ in $125 \mu \mathrm{l}$ of rehydration solution containing $80 \mu \mathrm{g}$ of protein, 2\% v/v IPG buffer pH 3-10, $40 \mathrm{mM}$ dithiothreitol (DTT), and DeStreak solution (GE-Healthcare). The first dimension gel was carried out in IPGphor Ettan III equipment with linear mode voltage (300 V for 12 h, 1,000 V for $30 \mathrm{~min}, 5,000 \mathrm{~V}$ for $2 \mathrm{~h}, 5000 \mathrm{~V}$ for $1 \mathrm{~h}$, and $200 \mathrm{~V}$ for $1 \mathrm{~h})$. After isoelectric focusing, the IPG strips were equilibrated in equilibration solution $(6 \mathrm{M}$ urea, $75 \mathrm{mM} \mathrm{Tris-} \mathrm{HCl}$ $\mathrm{pH} 8.8,29 \% \mathrm{v} / \mathrm{v}$ glycerol, $2 \% \mathrm{w} / \mathrm{v}$ sodium dodecyl sulfate (SDS), and 0.002\% w/v bromophenol blue), containing $1 \%$ DTT $\mathrm{w} / \mathrm{v}$ and $2.5 \% \mathrm{w} / \mathrm{v}$ iodoacetamide at different times, under agitation for $15 \mathrm{~min}$ each. The second dimension gel was carried out in a vertical electrophoresis Mini Protean II apparatus (Bio Rad, Hercules, California, USA), by SDS-PAGE using $14 \%$ acrylamide gels, at $80 \mathrm{~V}$ until the bromophenol blue front had reached the end of the gel. Gels were stained with colloidal Coomassie blue solution ( $8 \% \mathrm{w} / \mathrm{v}$ ammonium sulfate, $0.8 \% \mathrm{v} / \mathrm{v}$ phosphoric acid, 0.08\% w/v Coomassie blue G-250, and $20 \% \mathrm{v} / \mathrm{v}$ methanol for $36 \mathrm{~h}$ and stored in $5 \% \mathrm{v} / \mathrm{v}$ acetic acid solution. Three samples were used for gel electrophoresis, representing a triplicate.

The gel scanning was performed using Image Scanner III equipment (GE-Healthcare) in 16-bit transparency mode using red-blue and blue-green channels and with a resolution of $600 \mathrm{dpi}$. The images were analyzed using Image Master 2D Platinum 7.0 software (GE Healthcare).

\subsubsection{Separation by ion-exchange and reverse-phase high-performance liquid chromatography}

Another set of 80 venom reservoir were used, from which $2 \mathrm{ml}$ of the crude venom containing 1,500 $\mu \mathrm{g}$ of proteins were fractionated by ion-exchange chromatography (Mono-Q 5/50GL with quaternary ammonium ligand; GE Healthcare). The chromatographic separation was carried out using high-performance liquid chromatography (HPLC) (Waters Corporation, Milford, Massachusetts, USA) system. Elution of peptides was performed using a flow rate of $1 \mathrm{ml} / \mathrm{min}$ and monitored by following the absorbance at $220 \mathrm{~nm}$. Solvent A was $50 \mathrm{mM}$ sodium phosphate, pH 7.4, and solvent B was $50 \mathrm{mM}$ sodium phosphate and $1 \mathrm{M} \mathrm{NaCl}$. The linear gradient employed was 5-95\% B in 80 min and proteins of the venom were separated into eight fractions, which were collected every $10 \mathrm{~min}$. The fractions recovered after ionexchange chromatography separations were then fractionated by reverse phase on a C18 column (Protein \& Peptide 218TP54; Vydac) in HPLC system. Elution of peptides was performed using a flow rate of $1 \mathrm{ml} / \mathrm{min}$ and monitored by following the absorbance at 220 and $280 \mathrm{~nm}$. Solvent A was $0.1 \%$ trifluoroacetic acid (TFA) and solvent B was $80 \%$ acetonitrile $(A C N)$ and $0.1 \%$ TFA. The linear gradient employed was 5-95\% B in 65 min and proteins of the venom were separated into 130 fractions; these were collected every $30 \mathrm{sec}$.

\subsection{Samples digestion}

The spots obtained from two-dimensional gels were excised and dehydrated with 50\% v/v ACN and 20 mM ammonium bicarbonate, $\mathrm{pH}$ 8.0. After dehydration, the gels pieces were incubated sequentially with $65 \mathrm{mM}$ DTT for 30 min at $56^{\circ} \mathrm{C}$ and $200 \mathrm{mM}$ iodoacetamide for $30 \mathrm{~min}$ in the dark at room temperature, followed by washes in $100 \mathrm{mM}$ ammonium bicarbonate, $\mathrm{pH} 8.0$, and $100 \% \mathrm{v} / \mathrm{v}$ ACN. The gels pieces were treated with $10 \% \mathrm{v} / \mathrm{v}$ ACN and $40 \mathrm{mM}$ ammonium

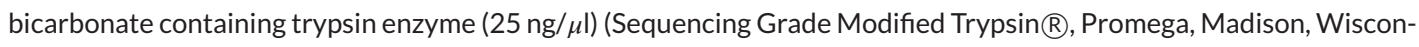
sin, USA) and incubated at $37^{\circ} \mathrm{C}$ for $16 \mathrm{~h}$. Peptides were extracted from the gel pieces by incubating then with $5 \% \mathrm{v} / \mathrm{v}$ formic acid and 50\% v/v ACN. The solution with the peptides was dried in the Speedvac and resuspended in $10 \mu$ of 
$0.1 \%$ v/v TFA. The samples were desalted using ZipTip pipette tips with C18 resin (Millipore, Billerica, Massachusetts, USA) according to the manufacturer's instructions, and then vacuum dried.

The samples from fractionation by reverse-phase chromatography were subjected to in-solution trypsin digestion. The fractions were dried in the Speedvac and resuspended in $100 \mathrm{mM}$ ammonium bicarbonate. After solubilized, the samples were reduced in $200 \mathrm{mM}$ DTT for $1 \mathrm{~h}$ at room temperature and then alkylated with 100 mM iodoacetamide under the same conditions, in the dark. To neutralize the alkylation process, 200 mM DDT (20 $\mu$ l) was added in the sample for $1 \mathrm{~h}$ at room temperature. Nonautolytic trypsin was added to protein sample ( $1 \mu \mathrm{g}$ per sample) for $18 \mathrm{~h}$ at $37^{\circ} \mathrm{C}$ and dried in the Speedvac. The samples were desalted under the same conditions described above. Both peptides samples from in-gel and in-solution digestion were analyzed by tandem mass spectrometry using matrix-assisted laser desorption/ionization with time-of-flight analyser (MALDI-TOF/TOF).

A third strategy was employed, a shotgun liquid chromatography-tandem mass spectrometry (LCMS/MS) approach, analyzing the peptides created from crude venom following in-solution digestion. For this methodology, a lyophilized aliquot of crude venom of $P$. striata containing $500 \mu \mathrm{g}$ of protein was solubilized in $100 \mathrm{mM}$ ammonium bicarbonate and submitted to reduction and alkylation under the same conditions described earlier. Nonautolytic trypsin was added to protein sample (1:50; $1 \mu \mathrm{g}$ trypsin: $50 \mu \mathrm{g}$ protein) for $18 \mathrm{~h}$ at $37^{\circ} \mathrm{C}$ and then dried in the Speedvac. The peptides were resuspended in $0.1 \% \mathrm{v} / \mathrm{v}$ formic acid and analyzed using liquid chromatography coupled to mass spectrometry (ESI-Q/TOF).

\section{3 | MASS SPECTROMETRY ANALYSIS}

\section{1 | MALDI-TOF/TOF}

Peptides obtained from in-gel and in-solution (following reverse-phase chromatography) digestion were solubilized in $0.1 \% \mathrm{v} / \mathrm{v}$ TFA and mixed with matrix [ $5 \mathrm{mg} / \mathrm{ml}$ 2,5-dihydroxybenzoic acid (DHB) and $\alpha$-cyano-4-hydroxy-cinnamic acid (mixture 1:1)] prepared in 50\% v/v ACN and 0.1\% v/v TFA. Peptides were applied to steel plate MTP Anchor Chip TM TF 600/384 (Bruker Daltonics, Bremen, Germany) and submitted to analysis on an Ultraflex III MALDI TOF/TOF mass spectrometer (Bruker Daltonics).

The spectra were acquired with the mass spectrometer operating in reflector mode (LPPepMix) for MS with mass range 500-5,000 Da and MS/MS spectra were acquired in LIFT mode (40-1,878 Da).

\subsection{ESI-Q/TOF}

Aliquots (30 $\mu \mathrm{l}$ ) of crude venom submitted to in-solution digestion containing 1 and $10 \mu \mathrm{g}$ of protein were separated by liquid chromatography (reverse phase-HPLC) (Shimadzu Corporation, Tokyo, Japan) coupled to the mass spectrometer (micrOTOF QII, Bruker Daltonics) equipped with microelectrospray ionization source. The liquid chromatography was performed using a total flow of $100 \mu \mathrm{l} / \mathrm{min}$, with UV detection (200-280 $\mathrm{nm}$ ) and column temperature controlled $\left(35^{\circ} \mathrm{C}\right)$. The spectrum was obtained from a detection range of $50-3000 \mathrm{~m} / \mathrm{z}$ in positive mode. For MS/MS analyses, ions with greater intensity were isolated as a precursor ion and generated fragment ions induced dissociation with collision energy $10 \mathrm{eV}$. Argon gas was used as collision gas.

\subsection{Protein identification}

The mass spectra obtained from MALDI-TOF/TOF were processed using FlexAnalysis 3.3 software (Bruker Daltonics) and peaks known to be contaminants were removed. The resulting mass list was submitted to identification using the software MASCOT (Matrix Science Ltd, UK; Peptide Mass Fingerprint, PMF, and MS/MS Ion Search). Spectra from MALDI-TOF/TOF and ESI-Q-TOF were searched against the NCBInr and SwissProt database with mass tolerance of 0.5 and 0.1 Da and 50 ppm error. Additional analysis was performed using PEAKS Studio 7.0 (Bioinformatic Solutions 


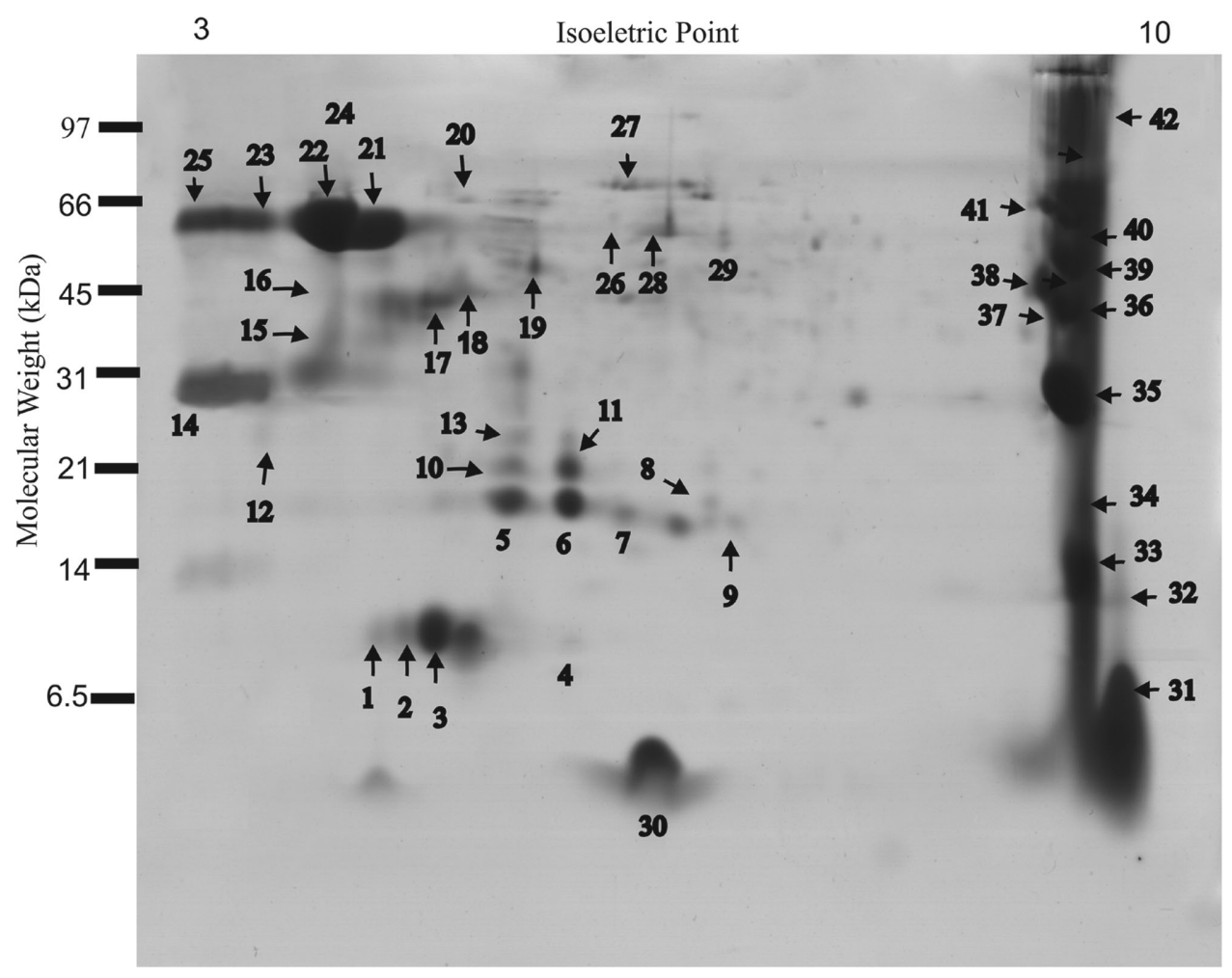

FIGURE 1 Two-dimensional polyacrylamide gel electrophoresis (14\%) of the venom proteins of Pachycondyla striata (Ponerinae), stained in colloidal Comassie blue solution, showing the proteins identified in MALDI-TOF/TOF (numbers) shown in Table 1

Inc., Waterloo, Canada) and the following search parameters were used: no restrictions on protein molecular weight; one tryptic missed cleave allowed; parent mass error tolerance 0.2 Da; and fragment mass errors tolerance 0.5 Da. In the data of both MALDI-TOF/TOF and ESI-Q-TOF analyses, carbamidomethylation of cysteine and oxidation of methionine were used as fixed and variable modifications, respectively. Ant (Formicidae), "proteins from animal venoms" (cone snails, snakes, insect, spider, amphibians), and Metazoa (Animals) ware selected as taxon for entry into databases. Significant result was considered when the score of the suggested protein was higher than the score calculated by the MASCOT software $(P<0.05$ and $P<0.01)$. A false discovery rate $(F D R)$ of $0 \%$ was used.

MS/MS spectra from MALDI-TOF-TOF were submitted to de novo sequencing using the program Biotools 3.2 (Bruker Daltonics) and MS/MS spectra from ESI-Q-TOF and MALDI-TOF-TOF using the program PEAKS Studio 7.0 (Bioinformatics Solutions Inc.), with average local confidence score (ALC) $\geq 70 \%$. The peptides sequences predicted by these programs were submitted to MS Blast research database (http://genetics.bwh.harvard.edu/msblast/) and the sequences that presented significant alignments with proteins derived from ants or animal venom databases were considered as positive identifications.

\section{4 | RESULTS}

Patterns of venoms from three different 2D gels showed a high similarity among them with high scatter plot correlation coefficient (>86\%). These gels showed the presence of 145 "spots" (protein) with molecular masses and isoelectric points ranged from 3.8 to $138.7 \mathrm{kDa}$ and 3.27 to 9.69, respectively (Figure 1). The MS1 and MS2 spectra (Supporting Information Figure 1) from the 2D gel samples resulted in the identification of 42 proteins (Table 1), with 26 from 


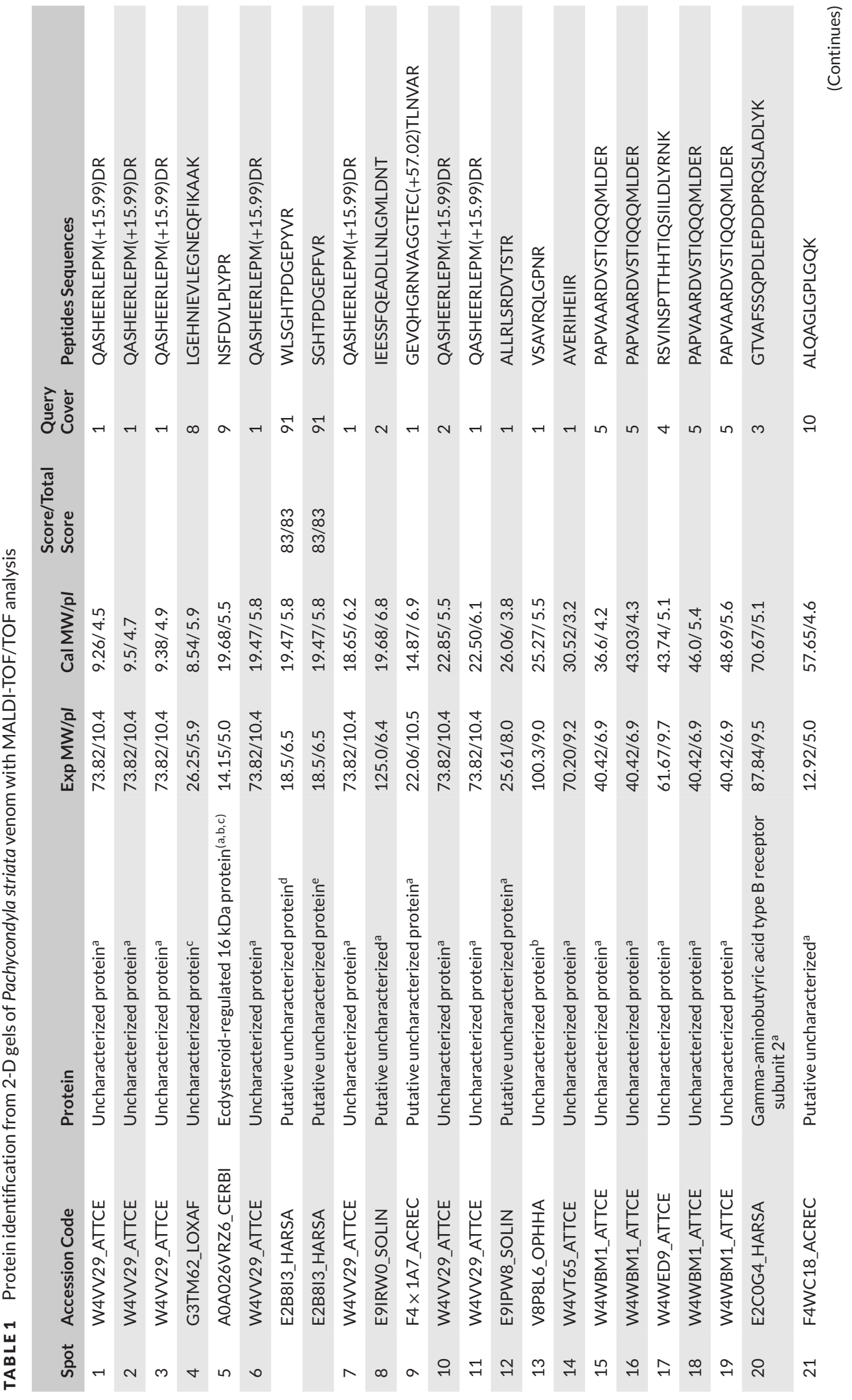




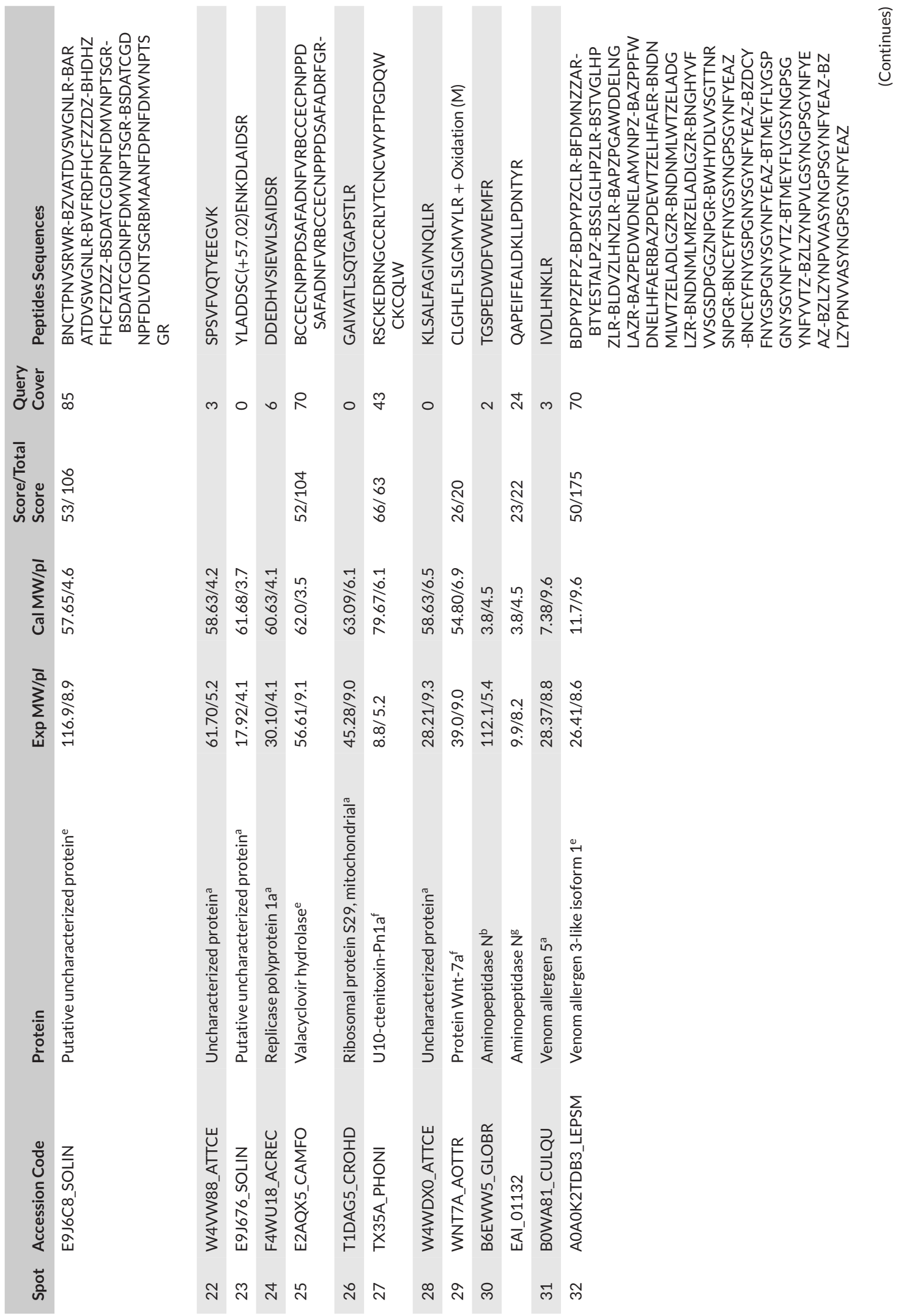




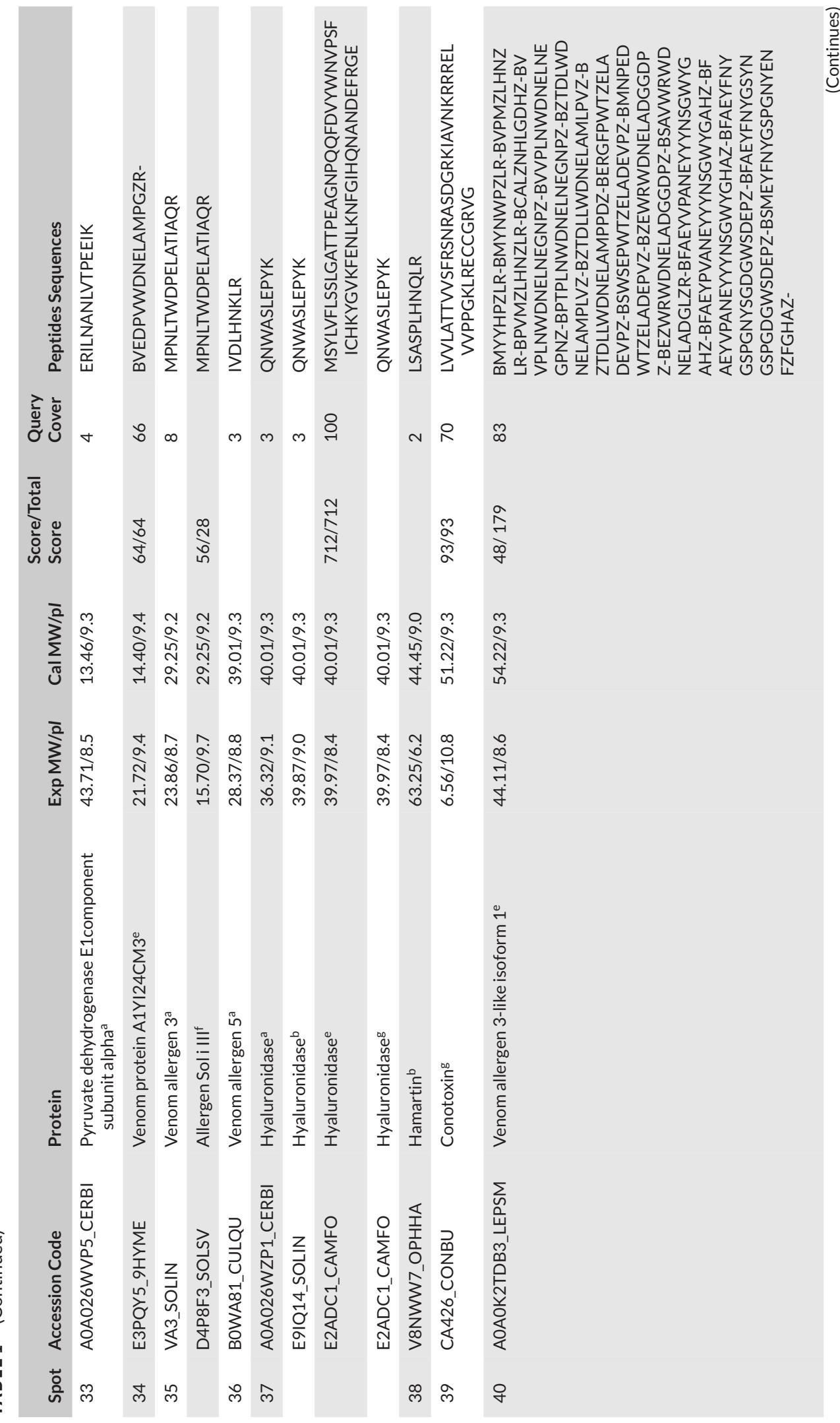




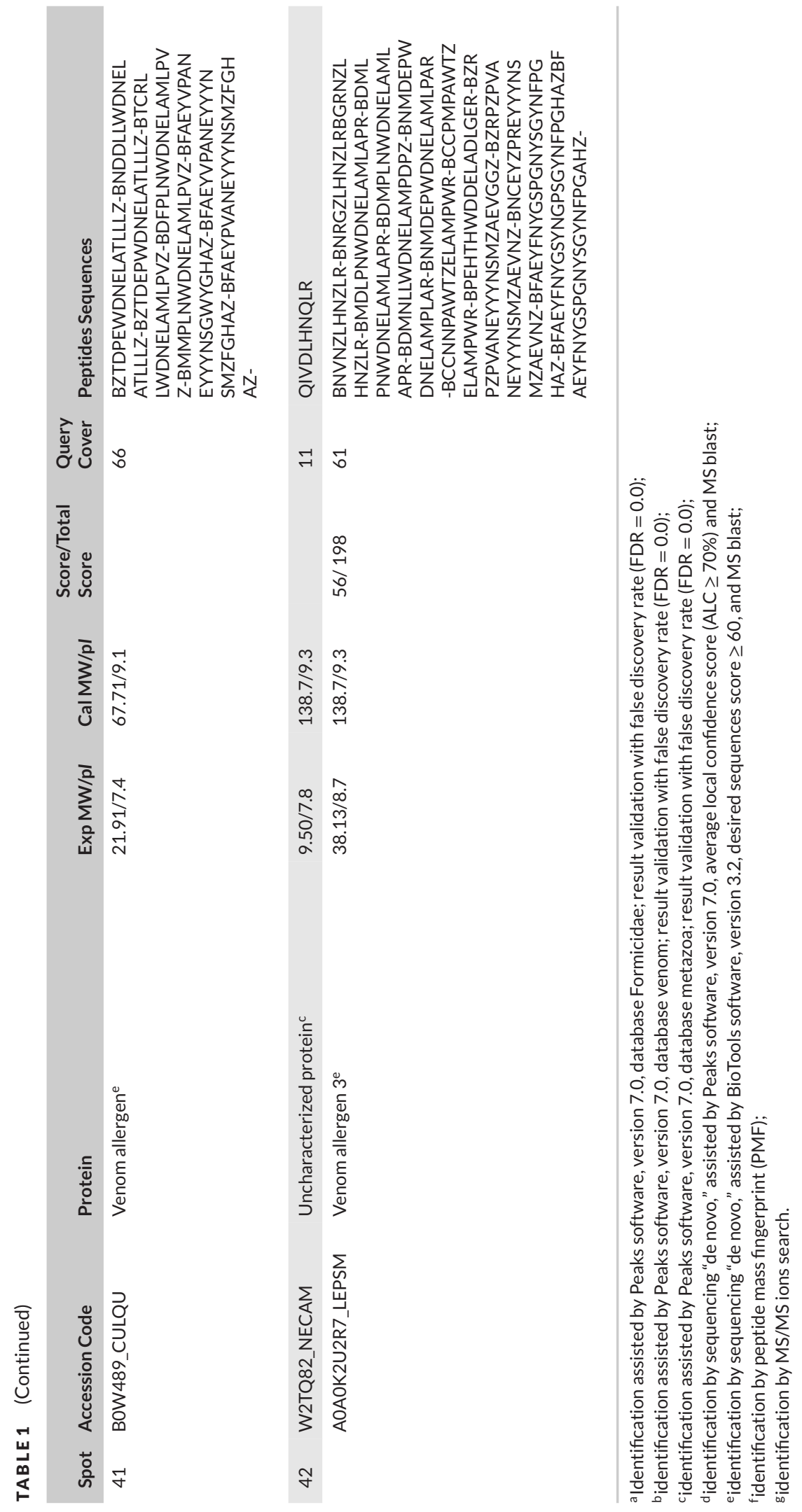




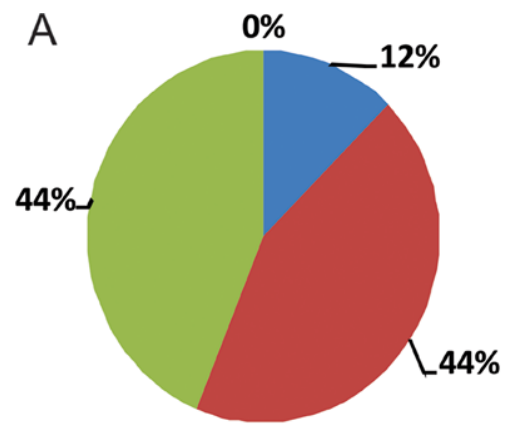

n Constitutive Proteins

- True Venom Proteins

- Putative Uncharacterized

Protein

- Body Muscle Proteins
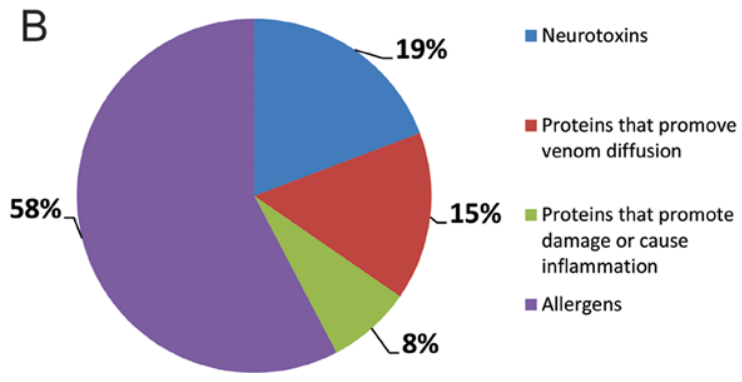

FIGURE 2 Overall classification of the proteins from the venom of the ant Pachycondyla striata (Ponerinae) based on functional protein groups. (A) Functional protein groups. (B) True venom components

ants (Cerapachys biroi, Harpegnathos saltator, S. invicta, Acromyrmex echinatior, S. saevissima, and Camponotus floridanus). Twenty two of the identified proteins were proteins inferred from the genome (spots 1-4, 6-19, 21-23, and 28). The spots 22 (Putative uncharacterized protein), 35 (venom allergen 3), 31 and 36 (Venom allergen 5), and 39 (Conotoxin) were the most abundant venom components, together they were almost $40 \%$ of the total volume of venom.

The MS/MS spectra of venom fractions obtained in reverse-phase HPLC, resulted in the identification of the protein Retroelement polyprotein from Lasius niger (Hymenoptera: Formicidae) and three venom allergens from of S. invicta, Pachycondyla chinensis (Hymenoptera: Formicidae), and Bombyx mori (Lepidoptera: Bombycidae), besides three unidentified proteins from S. invicta and Atta cephalotes (Hymenoptera: Formicidae) (Table 2).

A total of five proteins were identified through shotgun analysis, with four proteins (venom PLA1 2; hypothetical protein EAG_14340; hypothetical protein EAI_17579, coiled-coil-domain-containing protein 39) found in ants and one (basic PLA2 vurtoxin) from Vipera renardi (Squamata: Viperidae) (Table 2).

All proteins identified were classified into four different functional categories: constitutive cell proteins, true venom proteins, putative uncharacterized protein (Tables 3 and 4), and body muscle proteins (Figure 2A). The true venom proteins were classified into other four functional categories: neurotoxins, proteins that play a role in venom diffusion, proteins that cause damage or inflammation, and allergens, to simplify this data (Figure 2B).

\section{5 | DISCUSSION}

This is the first characterization of the venom proteins of $P$. striata. Our data show that the venom of $P$. striata is highly diverse, similar to the venom of other ants that have been characterized (Aili et al., 2014, 2017; Bouzid et al., 2014; Touchard et al., 2014). The combination of the three fractionation and analysis methods allowed the identification of 43 proteins in the venom of $P$. striata. Despite the good quality of the spectra obtained were found match to an entry in the database. Neurotoxins, proteins that promote venom diffusion or modulate prey defense mechanisms, proteins causing tissue damage or inflammation, and proteins that stimulate the production and/or antibodies reactions, are in 


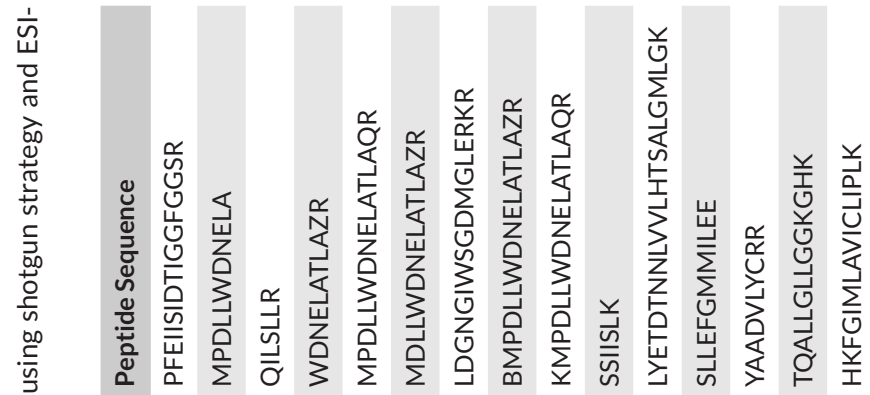

$\frac{0}{\frac{0}{0}}$

$\frac{\sqrt{n}}{n} \quad \frac{\tilde{v}}{4}$

导

$\infty_{\infty}^{\infty} \quad \frac{\infty}{\infty} \infty \frac{1}{\infty}$

華 인 웅

岂

능

๙

$\stackrel{\circ}{\circ}$

$\stackrel{\circ}{\circ}$

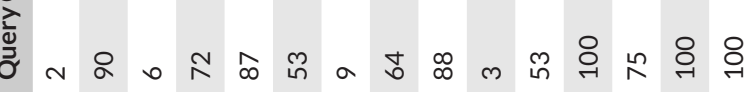

要

놈

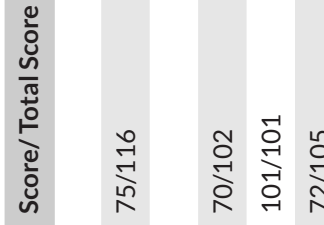

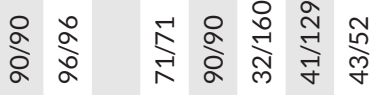

हैं

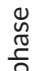

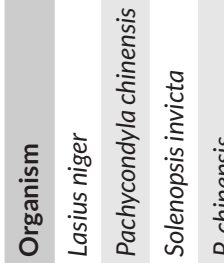

일

$\frac{1}{\grave{D}}$

.$\frac{1}{2}$

$\frac{1}{\frac{9}{2}}$

ঠे

$\frac{1}{8}$

.

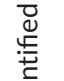

क्ष

돈

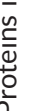
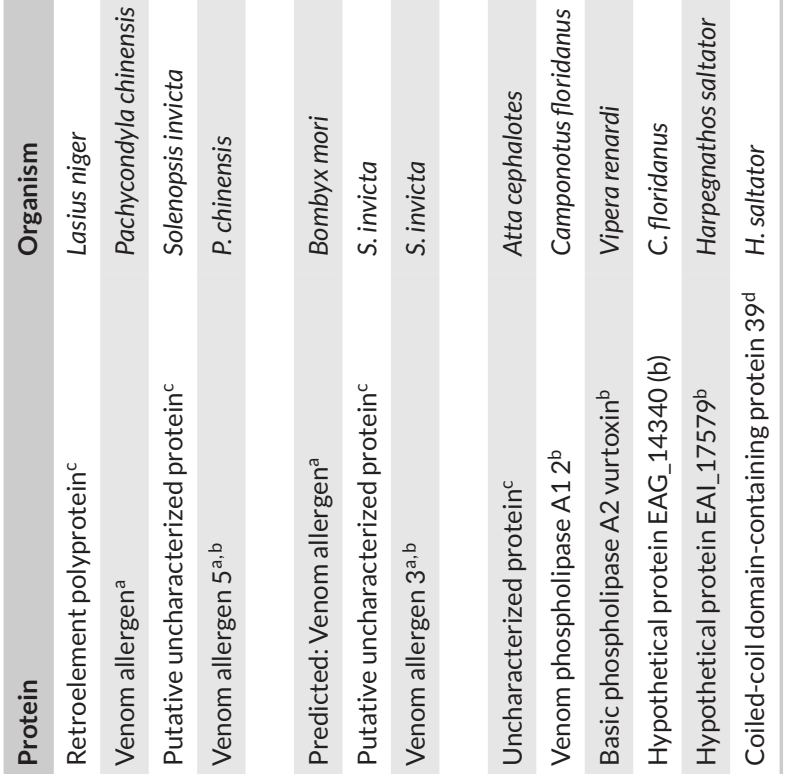

$\frac{\dot{n}}{\frac{\pi}{m}}$
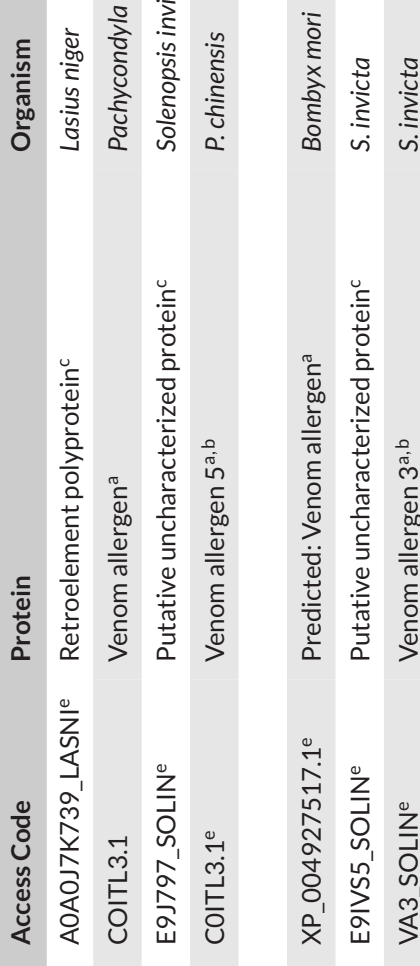

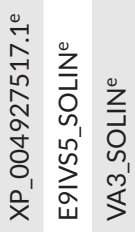

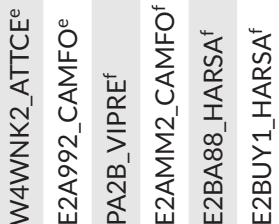

ขึ

으 ㅅ.

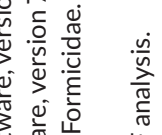



蛋芯岂

응

응 盛

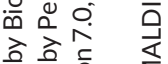

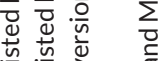

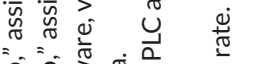

ه

bo



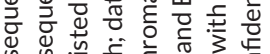

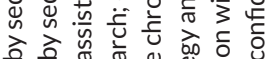

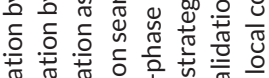

w u u

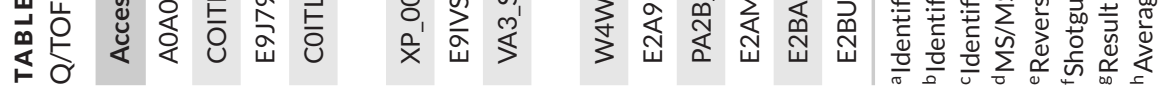




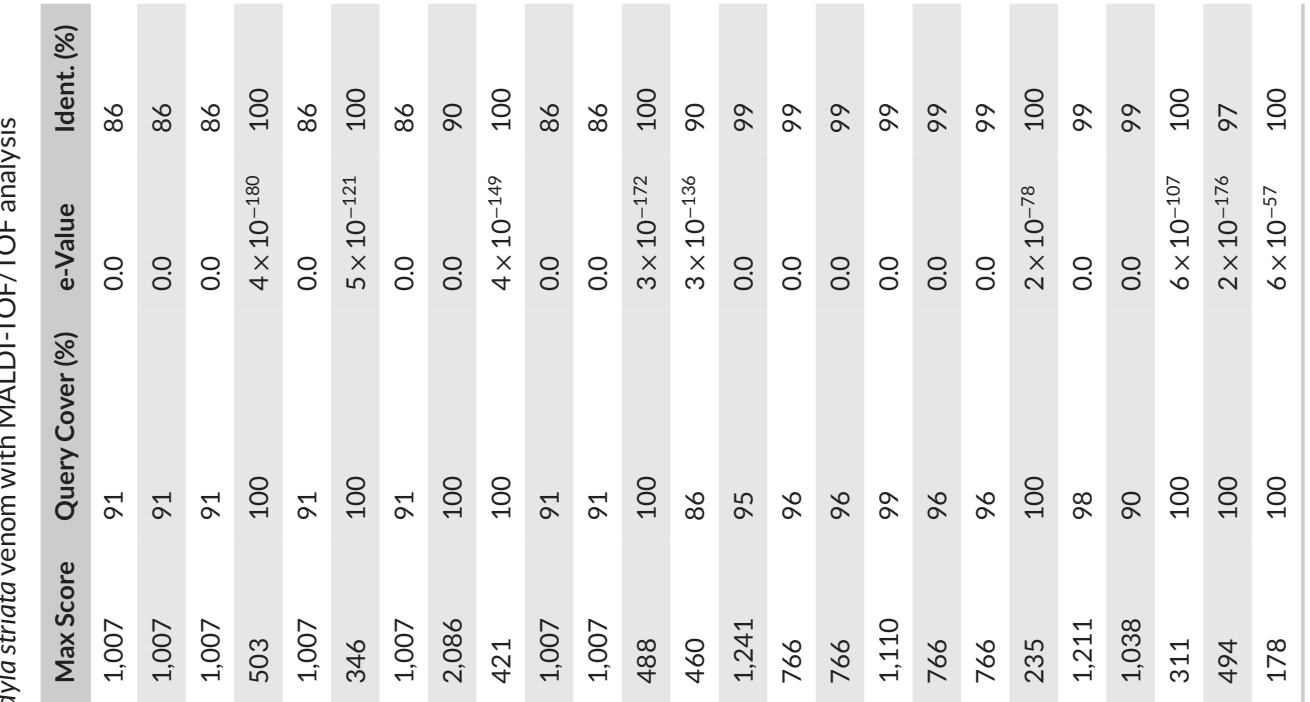

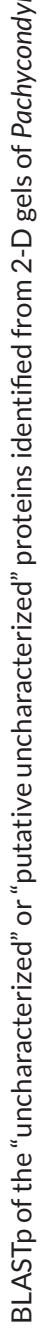

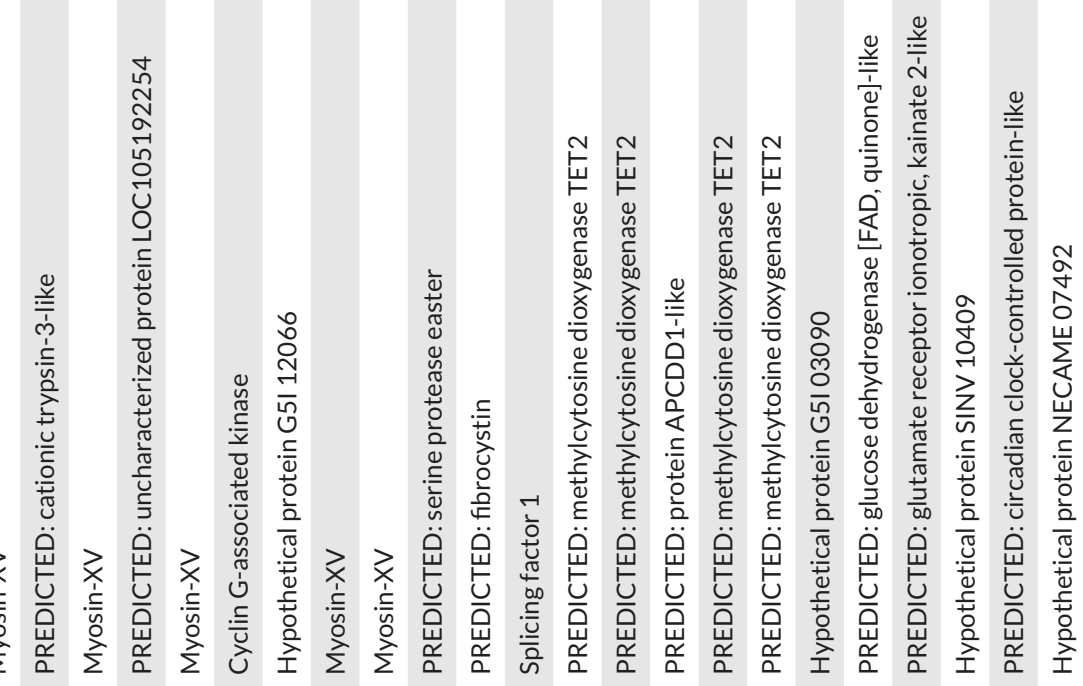

$$
\text { a }
$$


TAB LE 4 BLASTp of the "uncharacterized" or "putative uncharacterized" proteins identified in Pachycondyla striata venom from reverse-phase chromatography on HPLC and MALDI-TOF/TOF analysis, and using shotgun strategy with ESI-Q/TOF

\begin{tabular}{|c|c|c|c|c|c|c|}
\hline $\begin{array}{l}\text { Protein Access } \\
\text { Uniprot }\end{array}$ & $\begin{array}{l}\text { Protein Access } \\
\text { NCBInr }\end{array}$ & Protein Name & Max Score & $\begin{array}{l}\text { Query } \\
\text { Cover (\%) }\end{array}$ & e-Value & Ident. (\%) \\
\hline E9J797 & EFZ11306 & $\begin{array}{l}\text { Hypothetical protein } \\
\text { SINV } 09883\end{array}$ & 582 & 100 & 0.0 & 100 \\
\hline E9IVS5 & EFZ15328 & $\begin{array}{l}\text { Hypothetical protein } \\
\text { SINV } 00659\end{array}$ & 396 & 100 & $7 \times 10^{-140}$ & 100 \\
\hline W4WNK2 & KYM76259 & $\begin{array}{l}\text { Hypothetical protein } \\
\text { ALC53 } 13286\end{array}$ & 451 & 97 & $3 \times 10^{-159}$ & 95 \\
\hline
\end{tabular}

the venom of $P$. striata. Among the neurotoxic proteins present in the venom of $P$. striata, there are venom PLA1 2, basic PLA2 vurtoxin, conotoxin, and U10-ctenotoxin-Pn1a.

PLs are relatively common in ant venoms (Bouzid et al., 2014) and are among the most studied enzymes in the venom of Hymenoptera (Lima \& Brochetto-Braga 2003). In animals, four main types of PLs are known: PLA1, PLA2, PLB, and PLC (Touchard et al., 2016a). In the venom of $P$. striata, two different PLs are present: basic PLA2 vurtoxin and venom PLA1 2. The PLA1 and PLA2 catalyze the specific hydrolysis of ester bonds of 1,2-diacyl-3-sn glycerophospholipids in the positions sn- 1 and sn-2, respectively, converting these substrates into their corresponding lyso-associated compounds with the release of fatty acids (Santos et al., 2011)

PLA2 is among the most common PL found in ant venom (Touchard et al., 2016a), and has been described in the venom of different species (Pinto et al., 2012; Santos et al., 2011; Schmidt \& Blum, 1978; Touchard et al., 2016a), whereas PLA1 has been described in several Hymenoptera venoms (Hoffman, 1994; King, Lu, Gonzalez, Qian, \& Soldatova, 1996; Pinto et al., 2012). Venom PL from various animals have been described as a potent venom allergen (Lima \& Brochetto-Braga, 2003) with neurotoxic, platelet activation, hemolysis, and tissue damage effects (Pinto et al., 2012; Touchard et al., 2016a).

Conotoxin is a family of proteins that target and block potently a wide range of ion channels, such as voltagegated sodium, calcium, and potassium channels, as well as nicotinic acetylcholine and other membrane receptors (The Uniprot, 2017). Peptides that affect ion channels has been described frequently in some species of ants as: $H$. saltator and C. floridanus (Bonasio et al., 2010), S. invicta (Wurm et al., 2011), A. cephalotes (Suen et al., 2011), Cerapachys biroi (Oxley et al., 2014), A. echinatior (Nygaard et al., 2011), L. niger (The Uniprot, 2017), P. clavata (Piek et al., 1991), and E. tuberculatum (Pluzhnikov et al., 1999). Peptides of this group induce paralysis when injected into mice and fish (Lewis, Dutertre, Vetter, \& Christie, 2012). Pachycondyla striata is a predator species, possibly this peptide is involved in prey paralysis process.

The U10-ctenitoxin-Pn1a (fragment) found in P. striata is a TX3 family peptide present in the venom of the spider Phoneutria nigriventer and has potent neurotoxic effects, acting on ion channels, and chemical receptors of neuromuscular system of insects and mammals (Cardoso et al., 2003). The U10-ctenitoxin Pn1a is also known as neurotoxin Pn3-5A, described only in P. nigriventer (Cardoso et al., 2003), and so far its natural occurrence was not reported in none other animal species (The Uniprot, 2017). Despite showing homology (58\%, 48 amino acids) with TX3-5 toxin of P. nigriventer, this protein in $P$. striata has not conserved domain with another toxin or protein, suggesting that its physiological effects need further studies.

The presence of neurotoxins is not common in the venom of social insects due to the defensive nature of the venom in these insects (Pinto et al., 2012). However, P. striata is a predatory ant using their venom for both defense and predation. The presence of neurotoxins in the venom of $P$. striata may be related to its use in prey capture. The presence of compounds that paralyze or kill the prey quickly is important to the success of solitary foraging ants (Aili et al., 2014), as $P$. striata.

Proteins that promote venom diffusion or modulate prey defense mechanisms present in the venom of $P$. striata are hyaluronidase. This protein is a common in venom of ants, wasps, bees, and vertebrates (Pinto et al., 2012), and is a key 
enzyme for the diffusion of toxic molecules from the venom into the inoculated area of the prey/victim. This enzyme hydrolyses hyaluronic acid in the extracellular matrix of connective tissue decreasing the milieu viscosity, allowing rapid diffusion of venom toxins, potentiating their effect and damaging the tissue, contributing to the inflammatory process in the inoculated region (Kemparaju \& Girish, 2006). Hyaluronidases are in general among the more conserved hymenopteran allergens. In ants, enzymes with hyaluronidase activity are not described as a major component of the venom except for the Harvester ant Pogonomyrmex sp. (Bouzid et al., 2014) and they have low activity in comparison with those from social wasps (El-Safory, Fazary, \& Lee, 2010).

Among the proteins causing tissue damage or inflammation present in the venom of $P$. striata are aminopeptidase $N$ (APN), hyaluronidase, basic PL A2 vurtoxin, and venom PL A1 2, with the last three described above.

The APN is a multifunctional protease present in the venom of some snakes (Matteo et al., 2011) and in some organs, tissues, and cells, from bacteria to vertebrates (Chen, Lin, Peng, \& Li, 2012). In mammals, the APN play a role in the degradation of neuropeptides, cytokines, angiotensins (Ogawa, Murayama, Fujita, \& Yanoshita, 2007), and proteins (Matteo et al., 2011) and may be associated with the pain process (Chen et al., 2012). The presence of APN in P. striata venom may be involved in colony defense causing pain and injury in their enemies. In addition, as $P$. striata has carnivorous feeding habits, the presence of APN in its venom may be explained by the activity that this enzyme has on degradation of prey tissues, facilitating digestion. The aminopeptidases are among the poorly understood enzymes in the venom of snakes and other animals, and its real function remains unknown (Matteo et al., 2011).

The valacyclovir hydrolase and WNT-7a protein found in the venom of $P$. striata with the former described as enzyme and the second as rare in animal venom (The Uniprot, 2017). The WNT-7a protein occurs in some tissues of vertebrates and invertebrates binding to membrane receptors (Solis, Luchtenborg, \& Katanaev, 2013). Thus, WNT induces the release of intracellular calcium (Huelsken \& Birchmeier, 2001), resulting in cell necrosis. It is possible that valacyclovir hydrolase and WNT-7a protein play some role tissue damage, degrading proteins with damage to the prey.

Venom allergen 3 and allergen 5 were also found in the venom of $P$. striata, which stimulates antibody production and/or reactions. Venom allergen 3 (Sol i3) from the fire ant $S$. invicta is the major allergen of a series of Sol i peptides identified as the most frequent cause of hypersensitivity reactions following stings from this species (Padavattan, Schmidt, Hoffman, \& MarkovicHousley, 2008). This allergen has homology (44\% sequence identity) with Ves v 5 (allergen 5) from wasp venoms, which also occurs in P. striata here studied.

Venom allergens are among the most expressed proteins in the venom of $P$. striata. Additionally, the presence of venom PL A1 2, basic PL A2, hyaluronidase, U10-ctenitoxin, and proteins that also stimulate the production and/or antibodies reactions, suggest that $P$. striata has a venom with high allergenic potential.

Other proteins of $P$. striata venom identified are ribosomal protein S29, coiled-coil domain-containing protein 39, harmartin, pyruvate dehydrogenase E1 component subunit alpha, and retroelement polyprotein. The former is a mitochondrial protein, the second has conserved domain with cell cycle control protein, the third with membrane family proteins. The pyruvate dehydrogenase E1 component subunit alpha belongs to the thiamine pyrophosphate family and pyruvate dehydrogenase complex subfamily, which catalyzes the irreversible oxidative decarboxylation of pyruvate to acetyl-CoA in the bridging step between glycolysis and the citric acid cycle (https://www.ncbi.nlm.nih.gov/). The retroelement polyprotein interacts selectively and noncovalently with nucleic acids. All these proteins are probably soluble cellular proteins from the venom reservoir wall and/or convoluted gland present inside the reservoir (Ortiz \& Camargo-Mathias, 2006; Schoeters \& Billen, 1998), which may be ruptured during venom extraction contaminating the venom samples.

Twenty one (48\%) of the proteins identified in this study are inferred proteins from the genome. In addition various sequences with high level of confidence obtained from de novo analyses show the limited information available for P. striata and other ants in databases.

\section{ACKNOWLEDGMENTS}

The authors are grateful to Dr. Jacques Charles Hubert Delabie for identifying the species $P$. striata, to Mr. Manoel José Ferreira for assistance field collections, to the Núcleo de Biomoléculas from Federal University of Viçosa (UFV) 
for technical assistance. This research was supported by Brazilian research agencies CAPES, CNPq, FAPESP, FAPEMIG and FINEP.

\section{CONFLICT OF INTERESTS}

The authors declare no conflict of interest.

\section{ORCID}

José Eduardo Serrão (iD http://orcid.org/0000-0002-0477-4252

\section{REFERENCES}

Aili, S. R., Touchard, A., Escoubas, P., Padula, M. P., Orivel, J., Dejean, A., \& Nicholson, G. M. (2014). Diversity of peptide toxins from stinging ant venoms. Toxicon, 92, 166-178.

Aili, S. R., Touchard, A., Petitclerc, F., Dejean, A., Orivel, J., Padula, M. P., ... Nicholson, G. M. (2017). Combined peptidomic and proteomic analysis of electrically stimulated and manually dissected venom from the South American bullet ant Paraponera clavata. Journal of Proteome Research, 1, 1339-1351.

Baer, H., Liu, T. Y., Anderson, M. C, Blum, M., Schmid, W. H., \& James, F. J. (1979). Protein components of fire ant venom (Solenopsis invicta). Toxicon, 17, 397-405.

Bonasio, R., Zhang, G., Ye, C., Mutti, N. S., Fang, X., Qin, N., ... Liebig, J. (2010). Genomic comparison of the ants Camponotus floridanus and Harpegnathos saltator. Science, 329, 1068-1071.

Bouzid, W., Verdenaud, M., Klopp, C., Ducancel, F., Noirot, C., \& Vétillard, A. (2014). De novo sequencing and transcriptome analysis for Tetramorium bicarinatum: A comprehensive venom gland transcriptome analysis from an ant species. BMC Genomics, 18, 15-987.

Cardoso, F. C., Pacífico, L. G., Carvalho, D. C., Victória, J. M. N., Neves, A. L. G., Chávez-Olórtegui, C., ... Kalapothakis, E. (2003). Molecular cloning and characterization of Phoneutria nigriventer toxins active on calcium channels. Toxicon, 41, 755-763.

Casewell, N. R., Wuster, W., Vonk, F. J., Harrison, R. A., \& Fry, B. G. (2013). Complex cocktails: The evolutionary novelty of venoms. Trends in Ecology \& Evolution, 28, 219-229.

Chen, L., Lin, Y., Peng, G., \& Li, F. (2012). Structural basis for multifunctional roles of mammalian aminopeptidase N. Proceedings of the National Academy of Sciences, 109, 17966-17971.

Cologna, C. T., Cardoso, J. S., Jourdan, E., Degueldre, M., Upert, G., Gilles, N., ... Quinton, L. (2013). Peptidomic comparison and characterization of the major components of the venom of the giant ant Dinoponera quadriceps collected in four different areas of Brazil. Journal of Proteomics, 94, 413-422.

El-Safory, N. S., Fazary, A. E., \& Lee, C. (2010). Hyaluronidases, a group of glycosidases: Current and future perspectives. Carbohydrate Polymers, 81, 165-181.

Escoubas, P., Quinton, L., \& Nicholson, G. M. (2008). Venomics: Unravelling the complexity of animal venoms with mass spectrometry. Journal of Mass Spectrometry, 43, 279-295.

Hoffman, D. R. (1994). Allergens in hymenoptera venom. XXVI: The complete amino acid sequences of two vespid venom phospholipases. International Archives of Allergy and Immunology, 104, 184-190.

Huelsken, J., \& Birchmeier, W. (2001). New aspects of Wnt signaling pathways in higher vertebrates. Current Opinion in Genetics and Development, 11, 547-553.

Johnson, S. R., Copello, J. A., Evans, M. S., \& Suarez, A. V. (2010). A biochemical characterization of the major peptides from the venom of the giant neotropical hunting ant Dinoponera australis. Toxicon, 55, 702-710.

Kemparaju, K., \& Girish, K. S. (2006). Snake venom hyaluronidase: A therapeutic target. Cell Biochemistry and Function, $24,7-12$.

King, T. P., Lu, M. D. G., Gonzalez, M., Qian, N., \& Soldatova, L. (1996). Yellow jacket venom allergens, hyaluronidase and phospholipase: Sequence similarity and antigenic cross-reactivity with their hornet and wasp homologs and possible implications for clinical allergy. Journal of Allergy and Clinical Immunology, 98, 588-600.

Leluk, J., Schmidt, J., \& Jones, D. (1989). Comparative studies on the protein composition of hymenopteran venom reservoirs. Toxicon, 27, 105-114.

Lewis, J. C., Day, A. J., \& De La Lande, I. S. (1968). Phospholipase a in the venom of the Australian bulldog ant Myrmecia pyriformis. Toxicon, 6, 109-111. 
Lewis, R. J., Dutertre, S., Vetter, I., \& Christie, M. J. (2012). Conus venom peptide pharmacology. Pharmacological Reviews, 64, 259-298.

Lima, P. R., \& Brochetto-Braga, M. R. (2003). Hymenoptera venom review focusing on Apis mellifera. Journal of Venomous Animals and Toxins Including Tropical Diseases, 9, 1-11.

Mackay, W. P., \& Mackay, E. E. (2010). The systematics and biology of the New World ants of the genus Pachycondyla (Hymenoptera: Formicidae). Lewiston, NY: Edwin Mellen Press.

Maschwitz, U., Jessen, K., \& Maschwitz, E. (1981). Foaming in Pachycondyla: A new defense mecahnism in ants. Behavioral Ecology and Sociobiology, 9, 79-81.

Matteo, P., Arrigoni, G. L., Alberici, L., Corti, A., GalloStampino, C., Traversari, C., ... Rizzardi, G. (2011). Enhanced expression of CD13 in vessels of inflammatory and neoplastic tissues. Journal of Histochemistry \& Cytochemistry, 59, 47-59.

Morgan, E. D., Jungnickel, H., Keegans, S. J., Nascimento, R. R., Billen, J., Gobin, B., \& Ito, F. (2003). Comparative survey of abdominal gland secretions of the ant subfamily Ponerinae. Journal of Chemical Ecology, 29, 95-114.

Nygaard, S., Zhang, G., Schiøtt, M., Li, C., Wurm, Y., Hu, H., ... Boomsma, J. J. (2011). The genome of the leaf-cutting ant Acromyrmex echinatior suggests key adaptations to advanced social life and fungus farming. Genome Research, 21, 13391348.

Ogawa, Y., Murayama, N., Fujita, Y., \& Yanoshita, R. (2007). Characterization and cDNA cloning of aminopeptidase A from the venom of Gloydius blomhoffi brevicaudus. Toxicon, 49, 1172-1181.

Orivel, J., \& Dejean, A. (2001). Comparative effect of the venoms of ants of the genus Pachycondyla (Hymenoptera: Ponerinae). Toxicon, 39, 195-201.

Ortiz, G., \& Camargo-Mathias, M. I. (2006). Venom gland of Pachycondyla striata worker ants (Hymenoptera: Ponerinae): Ultrastructural characterization. Micron, 37, 243-248.

Oxley, P. R., Ji, L., Fetter-Pruneda, I., Mckenzie, S. K., Li, C., Hu, H., ... Kronauer, D. J. (2014). The genome of the clonal raider ant Cerapachys biroi. Current Biology, 24, 451-458.

Padavattan, S., Schmidt, M., Hoffman, D. R., \& Markovic-Housley, Z. (2008). Crystal structure of the major allergen from fire ant venom, Sol i 3. Journal Molecular Biology, 383, 178-185.

Pessoa, W. F. B., Silva, L. C. C., Dias, L. O., Delabie, J. H. C., Costa, H., \& Romano, C. C. (2016). Analysis of protein composition and bioactivity of Neoponera villosa venom (Hymenoptera: Formicidae). International Journal of Molecular Sciences, 17, 1-20.

Piek, T., Duval, A., Hue, B., Karst, H., Lapied, B., Mantel, P., .. Schmidt, J. O. (1991). Poneratoxin, a novel peptide neurotoxin from the venom of the ant, Paraponera clavata. Comparative Biochemistry and Physiology, 99, 487-495.

Pinto, J. R. A. S., Fox, E. G. P., Saidemberg, D. M., Santos, L. D., Menegasso, A. R. S., Costa-Manso, E., ... Palma, M. S. (2012). Proteomic view of the venom from the fire ant Solenopsis invicta Buren. Journal of Proteome Research, 11, 46434653.

Pluzhnikov, K., Nosyreva, E., Shevchenko, L., Kokoz, Y., Schmalz, D., Hucho, F., \& Grishin, E. (1999). Analysis of ectatomin action on cell membranes. European Journal of Biochemistry, 262, 501-506.

Rifflet, A., Gavalda, S., Téné, N., Orivel, J., Leprince, J., Guilhaudis, L., ... Treilhou, M. (2012). Identification and characterization of a novel antimicrobial peptide from the venom of the ant Tetramorium bicarinatum. Peptides, 38, 363-370.

Santos, L. D., Menegasso, A. R. S., Pinto, J. R. A. S., Santos, K. S., Castro, F. M., Kalil, J. E., \& Palma, M. S. (2011). Proteomic characterization of the multiple forms of the PLAs from the venom of the social wasp Polybia paulista. Proteomics, 1, 1403-1412.

Santos, L. D., Pieroni, M., Menegasso, A. R. S., Pinto, J. R. A. S., \& Palma, M. S. (2011). A new scenario of bioprospecting of hymenoptera venoms through proteomic approach. Journal of Venomous Animals and Toxins Incluinding Tropical Diseases, 17, 364-377.

Schmidt, J. O., \& Blum, M. S. (1978). The biochemical constituents of the venom of the harvester ant, Pogonomyrmex badius. Comparative Biochemistry and Physiology, 61, 239-247.

Schoeters, E., \& Johan, B. (1998). Venom gland ontogeny in formicinae, with special reference to the pulvinate convoluted gland (Hymenoptera: Formicidae). Zoomorphology, 118, 245-253.

Smith, P. K, Krohn, R. I., Hermanson, G. T., Mallia, A. K., Gartner, F. H., Provenzano, M. D., ... Klenk, D. C. (1985). Measurement of protein using bicinchoninic acid. Analytical Biochemistry, 150, 76-85.

Solis, G. P., Lüchtenborg, A., \& Katanaev, V. L. (2013). Wnt secretion and gradient formation. International Journal of Molecular Sciences, 14, 5130-5145.

Suen, G., Teiling, C., Li, L., Holt, C., Abouheif, E., Bornberg-Bauer, E., ... Currie, C. R. (2011). The genome sequence of the leafcutter ant Atta cephalotes reveals insights into its obligate symbiotic lifestyle. PLoS Genetics, 7, 1-11. 
Szolajska, E., Poznanski, J., Feber, M. L., Michalik, J., Gout, E., Fender, P., ... Chroboczek, J. (2004). Poneratoxin, a neurotoxin from ant venom structure and expression in insect cells and construction of a bio-insecticide. European Journal of Biochemistry, 271, 2127-2136.

The Uniprot Consortium. (2017). UniProt: the universal protein knowledgebase. Nucleic Acids Research, 45, D158-D169.

Touchard, A., Aili, S. R., Fox, E. G. P., Escoubas, P., Orivel, J., Nicholson, G. M., \& Dejean, A. (2016a). The biochemical toxin arsenal from ant venoms. Toxins, 8, 1-28.

Touchard, A., Brust, A., Cardoso, F. C, Chin, Y. K., Herzig, V., Jin, A. H., ... Escoubas, P. (2016b). Isolation and characterization of a structurally unique ßhairpin venom peptide from the predatory ant Anochetus emarginatus. Biochimica et Biophysica Acta, 1860, 2553-2562.

Touchard, A., Dauvois, M., Arguel, M., Petitclerc, F., Leblanc, M., Dejean, A., ... Escoubas, P. (2014). Elucidation of the unexplored biodiversity of ant venom peptidomes via MALDI-TOF mass spectrometry and its application for chemotaxonomy. Journal of Proteomics, 105, 217-231.

Touchard, A., Dejean, A., Escoubas, P., \& Orivel, J. (2015). Intraspecific variations in the venom peptidome of the ant Odontomachus haematodus (Formicidae: Ponerinae) from French Guiana. Journal of Hymenoptera Research, 47, 87-101.

Wiese, M. D., Chataway, T. K., Davies, N. W., Milne, R. W., Brown, S. G., Gai, W. P., \& Heddle, R. J. (2006). Proteomic analysis of Myrmecia pilosula (jack jumper) ant venom. Toxicon, 47, 208-217.

Wurm, Y., Wang, J., Riba-Grognuz, O., Corona, M., Nygaard, S., Hunt, B. G., ... Keller, L. (2011). The genome of the fire ant Solenopsis invicta. Proceeding of the National Academy of Sciences of the United States of America, 108, 5679-5684.

\section{SUPPORTING INFORMATION}

Additional Supporting Information may be found online in the supporting information tab for this article.

How to cite this article: Santos PP, Games PD, Azevedo DO, et al. Proteomic analysis of the venom of the predatory ant Pachycondyla striata (Hymenoptera: Formicidae). Arch Insect Biochem Physiol. 2017;96:e21424. https://doi.org/10.1002/arch.21424 